\title{
Dietary amenorrhoea and subclinical hypothyroidism with elevated TSH responsive to weight gain
}

\author{
*J. A. THOMSON \\ M.D., Ph.D., F.R.C.P.
}

\author{
$\dagger$ W. A. Ratcliffe \\ B.Sc., Ph.D.
}

\section{*University Department of Medicine, and $\nmid$ Radioimmunoassay Unit, Department of Pathological Biochemistry, Royal Infirmary, Glasgow}

\begin{abstract}
Summary
A case of dietary amenorrhoea associated with the biochemical picture of subclinical hypothyroidism is described. Both the amenorrhoea and the abnormal thyroid function tests reverted to normal on gaining weight.
\end{abstract}

\section{Introduction}

Thyroid tests are recognised to be abnormal in anorexia nervosa (Travaglini et al., 1976) and in more minor degrees of dietary amenorrhoea (Thomson, Baird and Thomson, 1977). The usual abnormalities are a low or low normal total serum thyroxine $\left(T_{4}\right)$ and triiodothyronine $\left(T_{3}\right)$ accompanied by a low level of thyroid-stimulating hormone (TSH) and in severe cases an elevated reverse $T_{3}\left(r T_{3}\right)$.

Other pituitary function can also be affected, for instance the plasma cortisol, growth hormone and prolactin may be elevated (Mecklenburg et al., 1974).

In this paper a different type of abnormality is reported, namely thyroid insufficiency with elevated TSH levels associated with dietary amenorrhoea, both conditions responding simultaneously to weight gain.

\section{Methods}

The following laboratory methods were used:

$\mathrm{T}_{4}$ and $\mathrm{T}_{3}$ by the semi-automated methods of Challand, Ratcliffe and Ratcliffe (1975). The normal ranges are $T_{4} 55-144 \mu \mathrm{mol} / 1$ and $T_{3} 0.9-2.8 \mathrm{nmol} / 1$.

Serum TSH was estimated by a double antibody radioimmunoassay method based on the method of Hall, Amos and Ormston (1971). The normal range is less than $8.0 \mathrm{mu} . / 1$.

Serum prolactin was estimated by the method of Cowden et al. (1979), normal range 60-360 mu./l.

\section{History}

A female aged 16 years 9 months was referred to hospital in September 1978 because of secondary amenorrhoea. Her menarche was at the age of 13 years and regular menstruation occurred untip February 1978 since when there was complete amenorrhoea. No obvious cause for this was detected on clinical examination but on detailed questioning she admitted dieting over the preceding year or soo She was $162.5 \mathrm{~cm}$ tall and usually weighed $54 \mathrm{~kg}$ but had dieted to $46.3 \mathrm{~kg}$ by April 1979. When seen iro September 1978 she weighed $44.5 \mathrm{~kg}$ and claimed to bef eating well. However, a dietary history showed her tơ be taking a diet of very low carbohydrate content. Her general health was good and she had no syrepeo toms of thyroid dysfunction.

Her general practitioner had checked her thyr\&id function tests which showed a total $\mathrm{T}_{4}$ of $58 \mathrm{nmol} / 1$ is a total $\mathrm{T}_{3}$ of $1.6 \mathrm{nmol} / \mathrm{l}$ and TSH $24 \mathrm{mu} . / \mathrm{l}$.

On examination she was a healthy looking buf underweight girl. Her skin was rather cool and driD but she had no other features of thyroid dysfunction $\Rightarrow$ In particular she had no goitre and no prolongeof relaxation phase of the tendon reflexes. Her pulserate was 70 beats/min and her BP $110 / 70 \mathrm{mmHg}$.

\section{Results of investigations}

Results of investigations in relation to her weight. gain are shown in Table 1. It will be noted that return? to normal weight coincided with correction of the abnormality of thyroid function tests and prolactin

At presentation, the FSH and LH were normab with values of $8 \cdot 2$ and $3 \cdot 1 \mathrm{u} . / 1$ respectively. X-ray of her pituitary fossa showed no abnormality. The

TABLE 1. Relationship of changes in body weight to levels thyroid hormones and prolactin

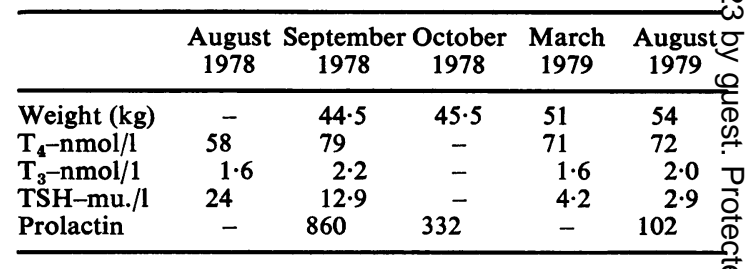


thyroid precipitin test for antibody to thyroglobulin was negative in August 1979.

The patient was advised to eat a more balanced diet. She regained her normal weight and began spontaneously to menstruate regularly in June 1979. With hindsight she now realises that she had been dieting quite strictly at the time of presentation.

\section{Discussion}

This patient presented the clinical picture of dietary amenorrhoea and had the biochemical picture of subclinical hypothyroidism with elevated TSH levels. Both problems resolved simultaneously with weight gain, and the elevated prolactin reverted to normal.

It could be argued that this represented the coincidental occurrence of dietary amenorrhoea with some incidental thyroid condition such as thyroiditis. There never was, however, any clinical evidence of thyroid disease, and the thyroid precipitin test was negative. Unfortunately, no uptake studies were performed at presentation.

Similarly, the initial elevated prolactin could be due to the stress of her initial hospital attendance. Elevated serum prolactins are, however, found in a proportion of patients with anorexia nervosa (Harrower et al., 1977).

It is tempting to argue that the amenorrhoea and abnormality of thyroid tests were related to the weight loss by means of some functional change in the hypothalamic/thyroid axis. Inappropriately high TSH levels have been described in the context of hypothalamic/pituitary disease (Faglia et al., 1973; Patel and Burger, 1973; Illig et al., 1975). In addition, there is a report of 24 children with protein-calorie malnutrition 8 of whom showed an elevated basal TSH value which reverted to normal levels on refeeding (Pimstone, Becker and Hendricks, 1973).

Previously, the authors have not encountered this pattern of thyroid function tests (which they suggest are in keeping with hypothalamic dysfunction and not primary thyroid disease) in the clinical problem of dietary amenorrhoea or anorexia nervosa, and the present case is reported in order to stimulate other physicians to look for similar examples in their patients.

\section{References}

Challand, G.S., Ratcliffe, W.A. \& Ratcliffe, J.G. (1975) Semi-automated radioimmunoassays for total serum thyroxine and tri-iodothyronine. Clinica chimica acta, 60, 25.

Cowden, E.A., Ratcliffe, W.A., Beastall, G.H. \& RATCLIFFE, J.G. (1979) Laboratory assessment of prolactin status. Annuals of Clinical Biochemistry, 16, 113.

Faglia, G., Beck-Peccoz, P., Ferrari, C., Ambrosi, B., Spada, A., Travaglini, P. \& Paracchi, S. (1973) Plasma thyrotrophin responses to thyrotrophin-releasing hormone in patients with pituitary and hypothalamic disorders. Journal of Clinical Endocrinology and Metabolism, 37, 595.

Hall, R., Amos, J. \& ORmston, B. (1971) Radioimmunoassay of human serum thyrotrophin. British Medical Journal, 1, 582.

Harrower, A.D.B., YaP, P.L., NaIRn, I.M., Walton, H.J., STrong, J.A. \& Craig, A. (1977) Growth hormone insulin and prolactin secretion in anorexia nervosa and obesity during bromocriptine treatment. British Medical Journal, 2, 156.

Illig, R., Krawczynska, H., Torresani, T. \& Prader, A. (1975) Elevated plasma TSH and hypothyroidism in children with hypothalamic hypopituitarism. Journal of Clinical Endocrinology and Metabolism, 41, 722.

MeCKlenburg, R.S., Loriaux, D.L., Thompson, R.H. ANDERSON, A.E. \& LipSETT, M.B. (1974) Hypothalamic dysfunction in patients with anorexia nervosa. Medicine, 53, 147.

Patel, Y.C. \& Burger, H.G. (1973) Serum thyrotrophin (TSH) in pituitary and/or hypothalamic hypothyroidism. Normal or elevated basal levels and paradoxical responses to thyrotrophin-releasing hormone. Journal of Clinical Endocrinology and Metabolism, 37, 190.

Pimstone, B., Becker, D. \& Hendricks, S. (1973) TSH response to synthetic thyrotrophin-releasing hormone in human protein-calorie malnutrition. Journal of Clinical Endocrinology and Metabolism, 36, 779.

Thomson, J.E., BAIRD, S.G. \& Thomson, J.A. (1977) Thyroid function in dietary amenorrhoea. Clinical Endocrinology, $1,383$.

Travaglini, P., Beck-Peccoz, P., Ferrari, C., Ambrosi, B., Paracchi, A., Severgnini, A., Spada, A., \& Faglia, G. (1976) Some aspects of hypothalamic pituitary function in patients with anorexia nervosa. Acta endocrinologica, 81, 252. 